\title{
KARSTIFICATION IN THE CUDDAPAH SEDIMENTARY BASIN, SOUTHERN INDIA: IMPLICATIONS FOR GROUNDWATER RESOURCES
}

\author{
ZAKRASEVANJE V SEDIMENTACIJSKEM BAZENU CUDDAPAH, \\ JUŽNA INDIJA: POSLEDICE ZA ZALOGE PODZEMNE VODE
}

\author{
Farooq Ahmad DAR ${ }^{1^{*}}$, Jerome PERRIN² , Jean RIOTTE ${ }^{3}$, Herbert Daniel GEBAUER ${ }^{4}$, Allu Chinna NARAYANA ${ }^{5}$ \\ \& Shakeel AHMED ${ }^{1}$
}

\begin{abstract}
UDC 551.435.8:556.33(540)

Farooq Ahmad Dar, Jerome Perrin, Jean Riotte, Herbert Daniel Gebauer, Allu Chinna Narayana \& Shakeel Ahmed: Karstification in the Cuddapah Sedimentary Basin, Southern India: Implications for Groundwater Resources

The Cuddapah sedimentary basin extends over a significant part of the southern part of Andhra Pradesh State, Southern India. Proterozoic carbonate rocks in the basin are constituted by as three main units- the Vempalle dolomite, the Narji and Koilkuntla limestones. These carbonate rocks are of strategic importance for local communities as they provide the main water source for irrigation and domestic use and they are also intensively quarried for cement production and building stones. It is therefore, of primary importance to assess to which extent these carbonate units are karstified so as to provide recommendations for appropriate land and water resource management. The field investigations carried out indicate that these carbonate units are significantly karstified and karstification has been an ongoing process with several phases under variable climatic conditions. As a result, a significant part of aquifer recharge occurs as point-recharge through swallow-holes and groundwater flow is channelized by conduit networks which emerge at karst springs. Karst development was possibly more active during past humid conditions; however karstification is still an ongoing process under the present semi-arid climate especially in the favorable case where karst drains the runoff issued from upstream quartzitic hills. The karstic nature of these carbonate units need to be integrated in future research and development programmes to avoid practices that may lead to unexpected collapses, reservoir leaks, inaccurate groundwater budgeting, etc.
\end{abstract}

Keywords: karst, karst aquifer, cave, semi-arid, groundwater resource, India.

\begin{abstract}
Izvleček
UDK 551.435.8:556.33(540)

Farooq Ahmad Dar, Jerome Perrin, Jean Riotte, Herbert Daniel Gebauer, Allu Chinna Narayana \& Shakeel Ahmed: Zakrasevanje v sedimentacijskem bazenu Cuddapah, južna Indija: Posledice za zaloge podzemne vode
\end{abstract}

Sedimentacijski bazen Cuddapah obsega pomemben del južnega dela indijske države Andhra Pradesh. Proterozojske karbonate sestavljajo tri glavne enote, Vempalle dolomit ter Narji in Koilkuntla apnenci. Ti karbonati so lokalno pomembni, saj predstavljajo glavni vodni vir za namakanje in gospodinjstva ter pomemben vir gradbenih materialov. Poznavanje stopnje zakraselosti karbonatov je lahko pomembno pri upravljanju vodnih virov in inženirskih posegih na območju. Terenske raziskave so pokazale veliko zakraselost omenjenih karbonatov; pomemben del napajanja vodonosnikov poteka točkovno, skozi ponore, pretakanje pa se vrši v dobro razviti mreži kraških kanalov. Glavna faza razvoja krasa je verjetno potekala v preteklih, bolj vlažnih obdobjih. Procesi zakrasevanja v današnji polsušni klimi so posebej intenzivni na območju, kjer se na kras steka voda iz kvarcitnega zaledja. Zakraselost karbonatov bo treba upoštevati pri upravljanju območja in bodočih razvojnih projektih. Le na ta način se bomo lahko izognili težavam, kot so puščanje iz jezov, udiranje, napačna ocena vodnih zalog in podobno.

Ključne besede: kras, kraški vodonosnik, jama, polsušno, zaloga podzemne vode, Indija.

\footnotetext{
${ }^{1}$ Indo-French Centre for Groundwater Research, CSIR-National Geophysical Research Institute (NGRI), Hyderabad, India, email: farooq.dar1@gmail.com

${ }^{2}$ Indo-French Centre for Groundwater Research (IFCGR), Hyderabad, India

${ }^{3}$ Indo-French Cell for Water Sciences (IFCWS), IRD, Bangalore, India

${ }^{4}$ German Karst and Cave Research Association, Munich, Germany

${ }^{5}$ Centre for Earth \& Space Sciences, University of Hyderabad

Received/Prejeto: 8.3.2011
} 


\section{INTRODUCTION}

Karst regions, representing about $15 \%$ of the continental landmass are widespread across the globe and present unique geomorphological characteristics which have specific consequences on land and water resources management (e.g. Ford \& Williams 2007). In India, karstified carbonate rocks are distributed across the country in different geomorphological, geological and climatic contexts (Himalayan region, North-eastern hills, and sedimentary basins in peninsular India, etc.). Regionally, these karstic zones play a vital role for the society both as a primary water supply and in economic terms (water resource for irrigated agriculture, quarrying for construction and cement production).

There are only a few studies on the characteristics and the role of karst in Indian carbonate terrains, and these publications mostly focus on groundwater resourc- es (e.g. Coward et al. 1972; Murty 1981; Shibasaki et al. 1985; Sing 1985; Chandra et al. 1987; Venkatanarayana \& Rao 1989; Venkatanarayana et al. 1999; Singh \& Dubey 2001; Dubey et al. 2006; Jeelani 2008).

The description of karst features and the understanding of karstification processes are important for an adequate land and water resource management because specific problems are known to occur in karst regions such as ground subsidence, sinkhole collapse, groundwater contamination and unpredictable water supply.

The present study aims at characterising the karstification of the main carbonate units situated within the Cuddapah sedimentary basin, southern Andhra Pradesh (Fig. 1), proposing a model of karstification, and evaluating the role of karstification on the groundwater resource.

\section{STUDY AREA}

The study area (Fig. 1) forms a part of the Cuddapah Basin of Proterozoic age. It lies in a semi-arid region with long hot dry summers with day temperature reaching $45^{\circ} \mathrm{C}$ and a well-defined monsoon season where most rainfall occurs as high intensity events. This study therefore, complements other karst studies in similar climatic realms which are still outnumbered (Jennings 1983).

\section{GEOLOGICAL SETTING}

The crescent shaped Cuddapah sedimentary basin is situated in the eastern part of the Dharwar Craton in the southern Andhra Pradesh, India (Fig. 1). Spreading over an area of about $44,500 \mathrm{~km}^{2}$, it is one of the extensive sedimentary basins of southern India (Narayanaswami 1966; Qureshi et al. 1968; King 1872; Crawford et al. 1973; Dutt 1975; Kailasam 1976; Murthy 1981; Kaila et al. 1985; Kale 1991; Ramam et al. 1997; Kasipathi et al. 2008; Raju 2009). The basin convexes towards west and extends for a length of about $400 \mathrm{~km}$ in north-south direction with a maximum width of $145 \mathrm{~km}$ in the middle.

The centre of the Cuddapah basin between Atmakur and Cuddapah is a broad flat plain drained by the Kundair and Pennar Rivers with a few scattered hills (e.g. mesa, butte) (Fig. 1). The plain descends from an elevation of $260 \mathrm{~m}$ at Atmakur to $130 \mathrm{~m}$ near Cuddapah. The plain is bounded on the west by flat topped Erramala Hills and the plateaus of Uppalapadu and Gandikota which slope gently easterly towards the plain. In the east, the Nallamala range defines steep $\mathrm{N}-\mathrm{S}$ trending rugged parallel ridges.

Sedimentary units of different rock assemblage are divided into two groups: Cuddapah and Kurnool groups of Proterozoic age separated by an unconformity (Meijerink et al. 1984) (Fig. 2).

The Archean aged peninsular gneissic complex constitutes the basement. The Cuddapah Supergroup is composed predominantly of arenaceous and argillaceous sequences with subordinate calcareous sediments, while the Kurnool Group has a more carbonate-rich geology. The lower Cuddapahs represents a cyclic repetition of quartzite-shale sequence while the Kurnool group shows two quartzite-limestone-shale sequences (Ramam et al. 1997). There was contemporaneous igneous activity manifested as sills, flows and other intrusive rocks in older sequences (Crawford et al. 1973; Ramam et al. 1997; Anand et al. 2003). The provenance of sediments was west and southwest (Pascoe 1950; King 1872). The shallow sub-marine shelf environment prevailed during the sedimentation of the basin (Shibasaki et al. 1985), whose depocenter was successively migrating towards east (Singh \& Mishra 2002).

The stratigraphy of the basin has been discussed by various geologists (Narayanaswami 1966; Sen \& Narsimha 1968; King 1872; Kaila et al. 1979; Ramam et al. 1997; Geological Survey of India (GSI) 1997). The younger Kurnool Group was deposited unconformably over the older Cuddapah Supergroup (Fig. 2). The Cud- 


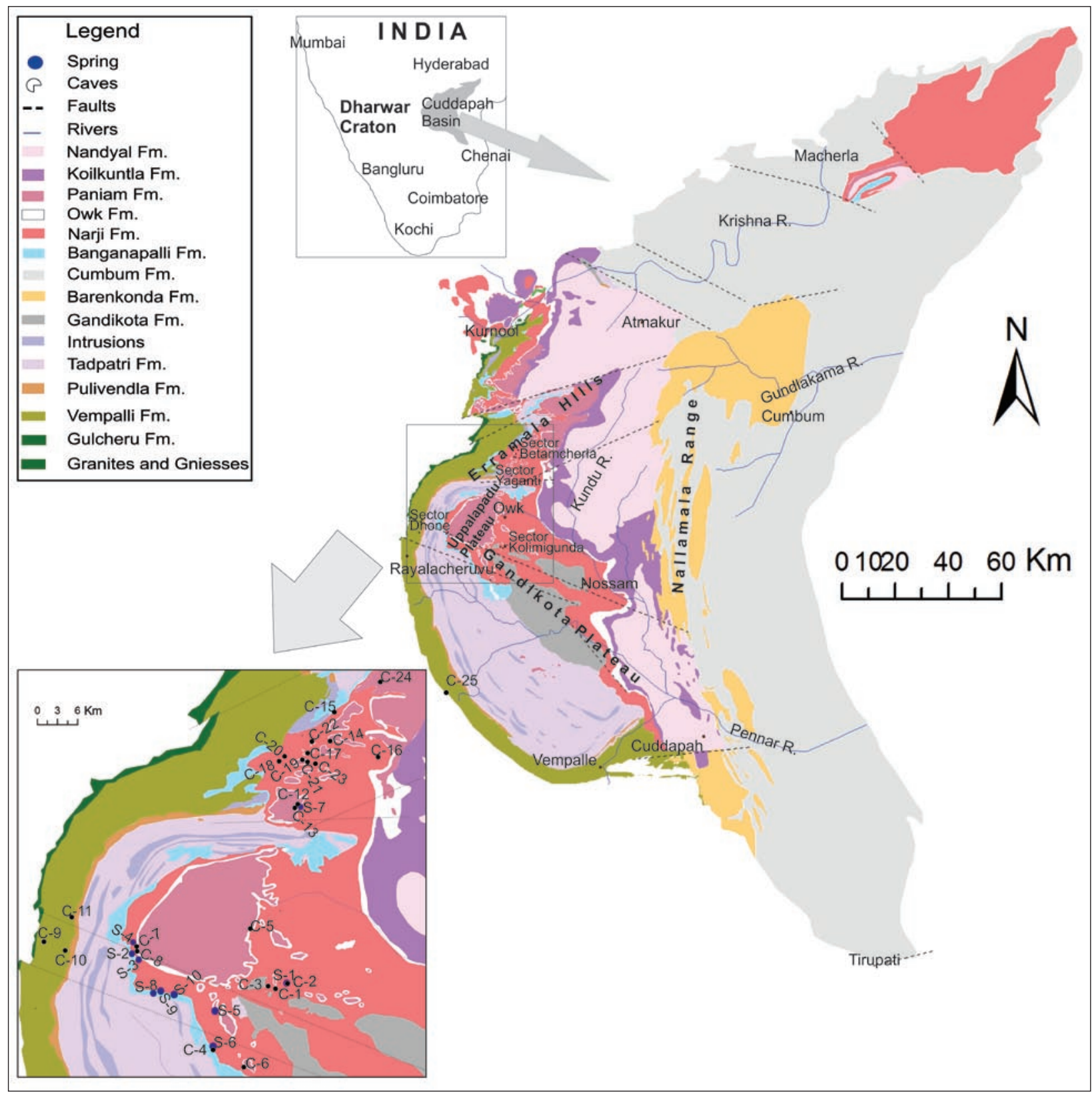

Fig. 1: Geological map of the Cuddapah sedimentary basin (modified from GSI 1997) and its location in the southern Indian peninsula. The location of caves $(C)$ and springs $(S)$ is also given.

dapah Supergroup has comparatively steeper dips than the easterly dipping Kurnool Group (Fig. 3). The general thickness of the whole sedimentary sequence is of the order of 6,000-12,000 m. The Kurnool System is thin, with maximum thickness of $370 \mathrm{~m}$ but it is superficially very extensive (Fig. 1).

The main carbonate rocks of the basin are the Vempalle Formation of the Cuddapah Supergroup and the Narji and Koilkuntla Formations of the Kurnool Group. Of the total area of the basin $\left(44,500 \mathrm{~km}^{2}\right), 17 \%$ (i.e. 7,690 $\mathrm{km}^{2}$ ) shows the exposure of these potentiallykarstified rocks. The areal extent of Vempalle, Narji and Koilkuntla Formations is 1,830, 4,333 and $1527 \mathrm{~km}^{2}$ respectively.

\section{Vempalle Formation}

The conglomeratic quartzite of Gulcheru Formation is conformably overlain by the thick Vempalle Formation constituted predominantly of dolomite (Fig. 2). The contact is gradational from quartzite to flaggy quartzite 


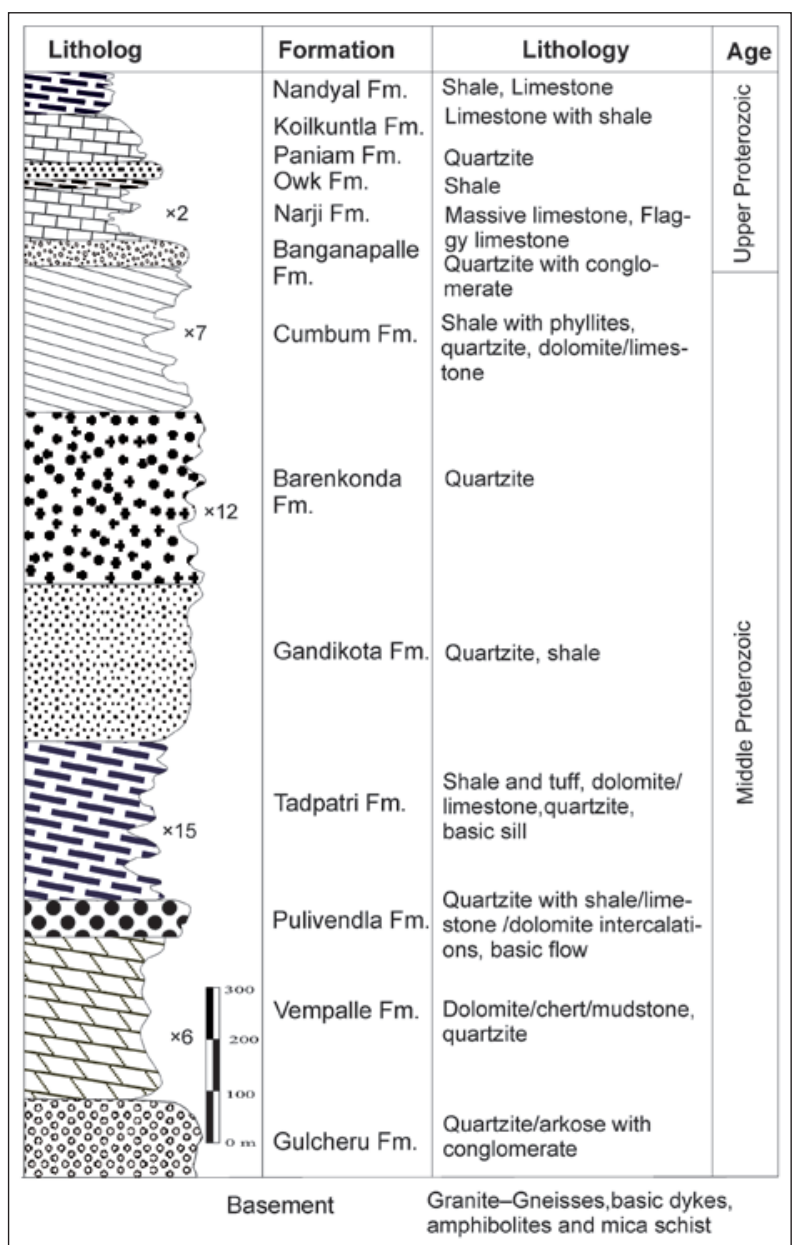

Fig. 2: Litholog showing the succession of rock formations encountered in the Cuddapah sedimentary basin.

to dolomite, with minor argillaceous sediments (Roy 1947; Anand et al. 2003). The lower part of the Vempalle sequence comprises of purple shale with interbedded layers of dolomite, succeeded by grey, greenish or brown dolomite with interbedded laminae of purple shale and beds of chert and intraformational conglomerates, which in turn is overlain by a purple and buff shale with thin dolomite layers and chert beds (Dutt 1962). The thickness of the Vempalle Formation varies from 1,250 to $1,900 \mathrm{~m}$ (Roy 1947; Jhanwar et al. 1964). It is the only stratigraphic unit in the Cuddapah sequence that contains a sequence of intrusive trap sills and pillow type lava flows. These rocks show some stromatolitic features (Vaidyanathan 1961; Riding \& Sharma 1998). This formation is well exposed in the western part of the Cuddapah Basin. The rocks generally strike NNE-SSW and dip $15-25^{\circ}$ towards east.

\section{Narji Formation}

The base of the Narji Formation starts with a highly siliceous pink and purple shale/shaly limestone with thin lenticular lenses of gritty ferruginous sandstone at some places. It grades into bluish-grey, high-grade massive limestone. The upper part of the limestone is flaggy (very regular $5-10 \mathrm{~cm}$ beds) that is mined for flooring and roofing material. At places where the formation rests over the Cuddapahs, the basal Banganapalle conglomerate of boulders and pebbles mark the transition between them. The lower part of the limestone shows interbedded shale, quartzite and intraformational conglomerates in several places (Dutt 1962).

The massive limestone is extremely fine grained, compact and gives a metallic sound. Narji limestone shows a dip of $0-10^{\circ}$ towards NE with a strike varying from NNW-SSE to NW-SE. The thickness of the Narji Limestone is quite variable: 0-192 m (Dutt 1962), 100200 m (Murthy et al. 1979; Murthy 1981; Nagaraja Rao et al. 1987) up to $100 \mathrm{~m}$ thick around Kurnool (Kamal 1974; Kamal \& Vijayam 1981; Vijayam et al. 1981). A litholog from Kolimigundla area showed $1 \mathrm{~m}$ of black soil, $30 \mathrm{~m}$ of flaggy limestone, $50 \mathrm{~m}$ of massive limestone, and a tectonic contact with Gandikota quartzite below. Some micro- and macro-stylolitic structures are also present. The rocks are overlain by the buff colored shale of the Owk Formation. These rocks extensively

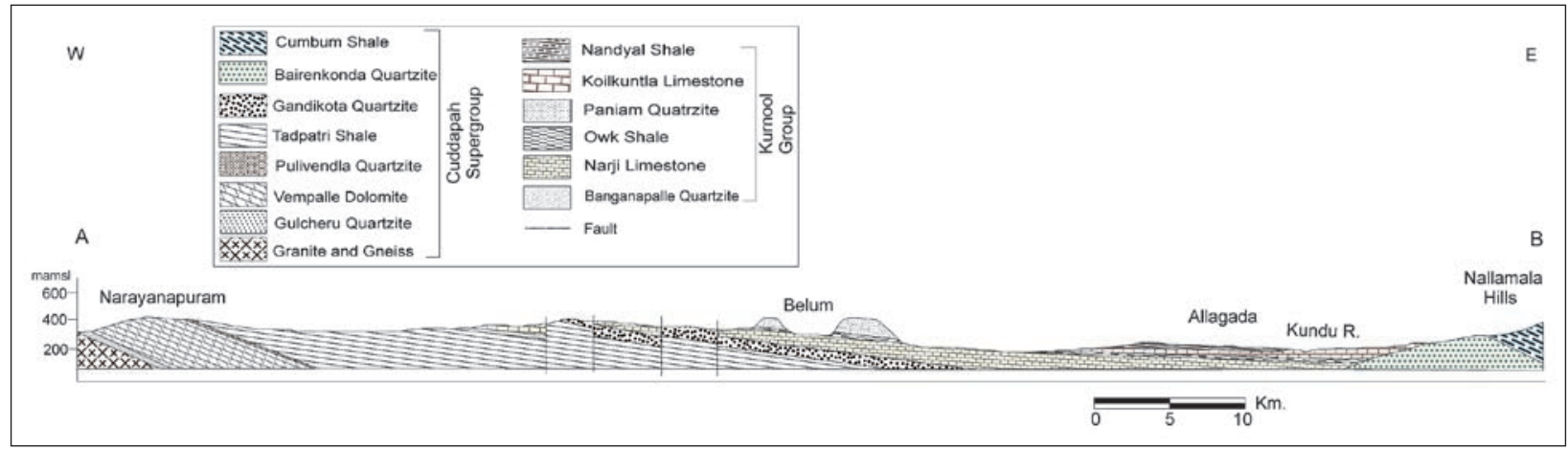

Fig. 3: Geological cross-section across the Cuddapah sedimentary basin showing the location of the three karstified formations (Vempalle, Narji, and Koilkuntla) (the trace of the cross-section is indicated in Fig. 1). 
outcrop in the western part of the Kundair valley, where the remnants of the overlying shale and quartzite occur in the form of small hillocks (mesas).

\section{Koilkuntla Formation}

The Koilkuntla Limestone is light to dark grey-colored, massive and flaggy in nature, overlying the Paniam quartzite. Extensively exposed in the Kundair valley, the formation spreads to the east up to the foot of the Nallamala range. The flaggy beds differ from Narji by possessing imperfect, wavy planes of bedding. The lower part of the formation includes the intercalation of shale and weathers to buff platy bits. The middle part of the formation is more calcareous, well bedded and tough. Towards the top the color of the limestone changes to purple and pass into Nandyal shale. The thickness ranges from 0-90 m (Dutt 1962). The purple Nandyal Shale with earthy calcareous intercalations, 50-100 m thick, overlies the Koilkuntla limestone.

\section{CLIMATE AND VEGETATION}

The Cuddapah basin climate is semi-arid with a dry season from December to May and a monsoon season from June to November. Mean annual temperature is $28.0^{\circ} \mathrm{C}$ (minimum $17{ }^{\circ} \mathrm{C}$ and maximum $44^{\circ} \mathrm{C}$ ) and average annual rainfall is $670 \mathrm{~mm}$. The monthly evaporation varies from 72-263 mm, with an annual total of $1,840 \mathrm{~mm}$ (Vittal et al. 2004). The aridity index is 0.36 which corresponds to the semi-arid class of UNEP (1992).

The main vegetation in the form of open scrub type jungles is scattered. Dense forests cover the Nallamala range. Other vegetation includes the rain-fed and irrigated crops that are mainly grown in the plains of Kundair valley. Major crops grown include paddy, oats, cotton, sunflower, groundnut and chilly. The chief economic activities include agriculture and mineral exploitation (cement, construction slabs).

\section{FIELD OBSERVATIONS}

\section{KARST FEATURES IN THE VEMPALLE DOLOMITE}

In this formation a typical landscape of hills dissected by valleys has developed; the hills have an asymmetric geometry with a gentle slope that follows the dip of the beds $\left(5-18^{\circ}\right)$ and a steeper slope on the opposite side. The origin of this morphology is not clear. In the area north of Rayala Cheruvu, these hills are elongated along a W-E axis. Hill width is between $400-800 \mathrm{~m}$ and length between $1,000-2,000 \mathrm{~m}$. Slopes on the western side is $>25^{\circ}$,

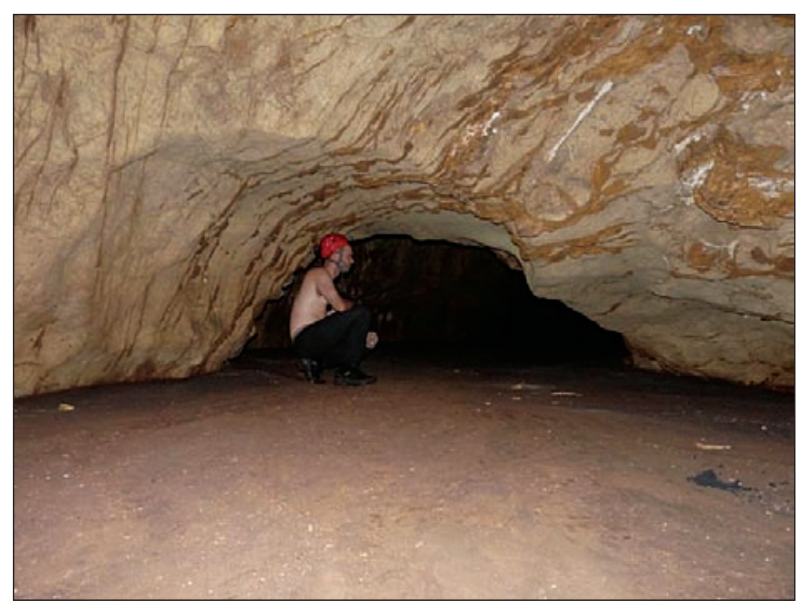

Fig. 4: Picture taken at the bottom of Kuruva Bali Guha (Vempalle dolomite) showing the phreatic shaped conduit and sediment accumulation on the floor. whereas on the eastern flank it is $<10^{\circ}$ (dip-slope). The hill height is between $100-150 \mathrm{~m}$.

The dolomite is karstified with existence of a few caves of limited extension (Tab. 1). The longest cave is "Kuruva Bali Guha" C11 (318 m in length, $77 \mathrm{~m}$ in depth) which is also the deepest known cave in southern India (Gebauer 1985). This cave shows presence of infiltration water during the monsoon (from observations on the soil of the deepest part, it seems that a stream is meandering through the clay/silt deposits and possibly some water filling occurs after intense recharge, Fig. 4). The geological cross-section of the area (Fig. 5) shows that the cave ends near the bottom of the valley which constitutes the base level. Recharge occurs seasonally on the hills and feeds the fissured-karstified dolomite aquifer with a water table close to the valley bottom. In the valleys, irrigation wells exhibit quite variable discharge and some wells are dry. This is typical of a highly heterogeneous aquifer. No karst springs are known and it is possible that natural discharge occurs within the alluvial deposits of the main valleys.

\section{KARST FEATURES IN THE NARJI LIMESTONE}

The Narji limestone occupies a vast planar region surrounded by smooth topped hills of Gandikota quartzite (mostly in the Western part) and from place to place, by mesas of Owk shale and Paniam quartzite (Figs. $6 \& 7$ ). 
Tab. 1: List of the natural caves developed in two of the three karstified formations of the Cuddapah basin (compilation of original data and data published in Gebauer 1985, 1997, and Gebauer \& Abele 1983). The caves are located either on Fig. 1 or Fig. 6.

\begin{tabular}{|c|c|c|c|c|c|c|c|c|}
\hline & ID & Cave name & Longitude & Latitude & \begin{tabular}{|l} 
Length \\
{$[\mathrm{m}]$}
\end{tabular} & \begin{tabular}{|l} 
Depth \\
{$[\mathrm{m}]$}
\end{tabular} & Geology & Reference \\
\hline \multirow{6}{*}{$\begin{array}{l}\text { Sector } \\
\text { Kolimigundla }\end{array}$} & $\mathrm{C} 1$ & Belum Guhalu & $78^{\circ} 06^{\prime} 41.4^{\prime \prime}$ & $15^{\circ} 06^{\prime} 7.6^{\prime \prime}$ & 3225 & -29 & Narji lim. & Gebauer 1983, 1985 \\
\hline & $\mathrm{C} 2$ & Belum Karst Spring & $78^{\circ} 07^{\prime} 30.0^{\prime \prime}$ & $15^{\circ} 06^{\prime} 47.2^{\prime \prime}$ & 65 & & Narji lim. & Gebauer 1983 \\
\hline & $\mathrm{C} 3$ & Chirutipuli Guha & 7806'06.7" & $15^{\circ} 06^{\prime} 19.5^{\prime \prime}$ & 92 & -9 & Narji lim. & Gebauer 1983, 1985 \\
\hline & C4 & Bugga Guhalu & $78^{\circ} 01^{\prime} 30.3^{\prime \prime}$ & $15^{\circ} 00^{\prime} 34.8^{\prime \prime}$ & $>10$ & & Narji lim. & \\
\hline & $\mathrm{C5}$ & Nela Bilam & $78^{\circ} 04^{\prime} 27.12^{\prime \prime}$ & $15^{\circ} 10^{\prime} 59.04^{\prime \prime}$ & $>100$ & -14 & Narji lim. & Gebauer 1985 \\
\hline & C6 & Bandarlapalle Guha & $78^{\circ} 04^{\prime} 12.2^{\prime \prime}$ & $14^{\circ} 59^{\prime} 37.3^{\prime \prime}$ & 117 & -18 & Narji lim. & \\
\hline \multirow{5}{*}{ Sector Dhone } & $\mathrm{C7}$ & Munagamanu Gavi & $77^{\circ} 55^{\prime} 9^{\prime \prime}$ & $15^{\circ} 09^{\prime} 11.2^{\prime \prime}$ & 864 & -16 & Narji lim. & Gebauer 1985, 1997 \\
\hline & C8 & Udagamanu Gavi & $77^{\circ} 54^{\prime} 57.9^{\prime \prime}$ & $15^{\circ} 09^{\prime} 0^{\prime \prime}$ & 100 & & Narji lim. & Gebauer 1997 \\
\hline & C9 & Panchalingalaswami Guha & $77^{\circ} 47^{\prime} 10.0^{\prime \prime}$ & $15^{\circ} 09^{\prime} 35.0^{\prime \prime}$ & 58 & -10 & Vempalle dol. & Gebauer 1985 \\
\hline & $\mathrm{C} 10$ & Langu Gavi & $77^{\circ} 49^{\prime} 43.0^{\prime \prime}$ & $15^{\circ} 11^{\prime} 39.0^{\prime \prime}$ & 65 & & Narji lim. & Gebauer 1997 \\
\hline & C11 & Kuruva Bali Guha & $77^{\circ} 49^{\prime} 04.8^{\prime \prime}$ & $15^{\circ} 09^{\prime} 00.2^{\prime \prime}$ & 318 & -77 & Vempalle dol. & Gebauer 1985 \\
\hline \multirow{2}{*}{ Sector Yaganti } & C12 & Yaganti caves & $78^{\circ} 8^{\prime} 23.7^{\prime \prime}$ & $15^{\circ} 21^{\prime} 3.1^{\prime \prime}$ & 139 & & Narji lim. & Gebauer 1983 \\
\hline & C13 & Yerra Zari Gabbi & $77^{\circ} 08^{\prime} 11.5^{\prime \prime}$ & $15^{\circ} 20^{\prime} 49.9^{\prime \prime}$ & 684 & -48 & Narji lim. & Gebauer 1983 \\
\hline \multirow{11}{*}{$\begin{array}{l}\text { Sector } \\
\text { Betamcherla }\end{array}$} & C14 & Bila Sorgam & $78^{\circ} 11^{\prime} 7.1^{\prime \prime}$ & $15^{\circ} 26^{\prime} 13.1^{\prime \prime}$ & 700 & -40 & Narji lim. & Gebauer 1983 \\
\hline & C15 & Sanyasula Gavi & $78^{\circ} 10^{\prime} 50^{\prime \prime}$ & $15^{\circ} 28^{\prime} 40^{\prime \prime}$ & 234 & -18 & Narji lim. & Gebauer 1983, 1985 \\
\hline & C16 & Kottala Guhalu & $78^{\circ} 15^{\prime}$ & $15^{\circ} 25^{\prime}$ & 65 & 5 & Narji lim. & Gebauer 1983 \\
\hline & C17 & Nemmalasilla Gavi & $78^{\circ} 09^{\prime} 02^{\prime \prime}$ & $15^{\circ} 25^{\prime} 15^{\prime \prime}$ & 35 & & Narji lim. & Gebauer 1997 \\
\hline & C18 & Muchchatleswara Gavi & $78^{\circ} 06^{\prime} 43^{\prime \prime}$ & $15^{\circ} 24^{\prime} 35^{\prime \prime}$ & 50 & & Narji lim. & Gebauer 1997 \\
\hline & C19 & Boya Dari Gavi & $78^{\circ} 08^{\prime} 45^{\prime \prime}$ & $15^{\circ} 24^{\prime} 40^{\prime \prime}$ & 40 & & Narji lim. & Gebauer 1997 \\
\hline & $\mathrm{C} 20$ & Chintamanu Gavi & $78^{\circ} 07^{\prime} 12^{\prime \prime}$ & $15^{\circ} 24^{\prime} 55^{\prime \prime}$ & 100 & & Narji lim. & Gebauer 1997 \\
\hline & C21 & Errabadde Caves & $78^{\circ} 09^{\prime} 06^{\prime \prime}$ & $15^{\circ} 24^{\prime} 35^{\prime \prime}$ & 60 & & Narji lim. & Gebauer 1997 \\
\hline & $\mathrm{C} 22$ & Road cave & $78^{\circ} 09^{\prime} 34.7^{\prime \prime}$ & $15^{\circ} 26^{\prime} 06.7^{\prime \prime}$ & 20 & & Narji lim. & \\
\hline & C23 & Jan Galu Gavi & $78^{\circ} 09^{\prime} 50^{\prime \prime}$ & $15^{\circ} 24^{\prime} 25^{\prime \prime}$ & 40 & -17 & Narji lim. & Gebauer 1997 \\
\hline & C24 & Krishnammakona 5 & $78^{\circ} 15^{\prime}$ & $15^{\circ} 31^{\prime}$ & 140 & & Narji lim. & Gebauer 1997 \\
\hline Other area & $\mathrm{C} 25$ & Chillavaripalle cave & $77^{\circ} 50^{\prime} 06.4^{\prime \prime}$ & $14^{\circ} 36^{\prime} 43.7^{\prime \prime}$ & 86 & -7 & Vempalle dol. & Shibasaki 1985 \\
\hline
\end{tabular}

W

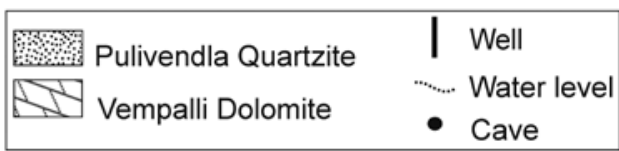

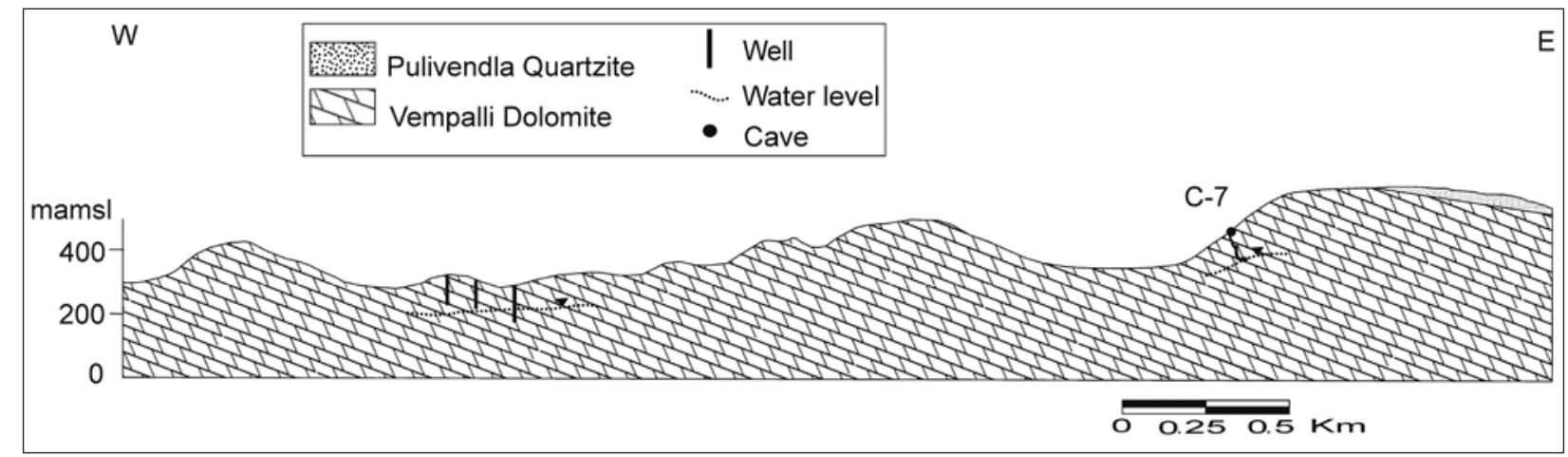

Fig. 5: Geological cross-section across the Vempalle dolomite with representation of the main known cave and inferred piezometric surface based on observations in the cave and existing borewells in the surroundings.

The massive limestone is well karstified and contains the major caves of southern India (Tab. 1). Several typologies of caves could be identified: 1) network maze caves in the upper part of the limestone near the contact with Owk shale (Nila Bilam, Yerra Zari Gabi caves), 2) dendritic/anastomotic cave patterns of phreatic origin (Belum cave), 3) meander cave mostly formed under vadose flow regime (Munagamanu cave) (Fig. 8). At the foot of quartzite hills, a significant number of swallowholes are observed and during the monsoon streams issued from the hills will infiltrate within a few hundred meters after reaching the limestone plain (Fig. 6). These recharge events generates significant water level rise in the karstic network and activate seasonal springs. The hydrograph of one of these springs (Fig. 6: S1, Belum spring) shows a sharp reaction to the rainfall events and 


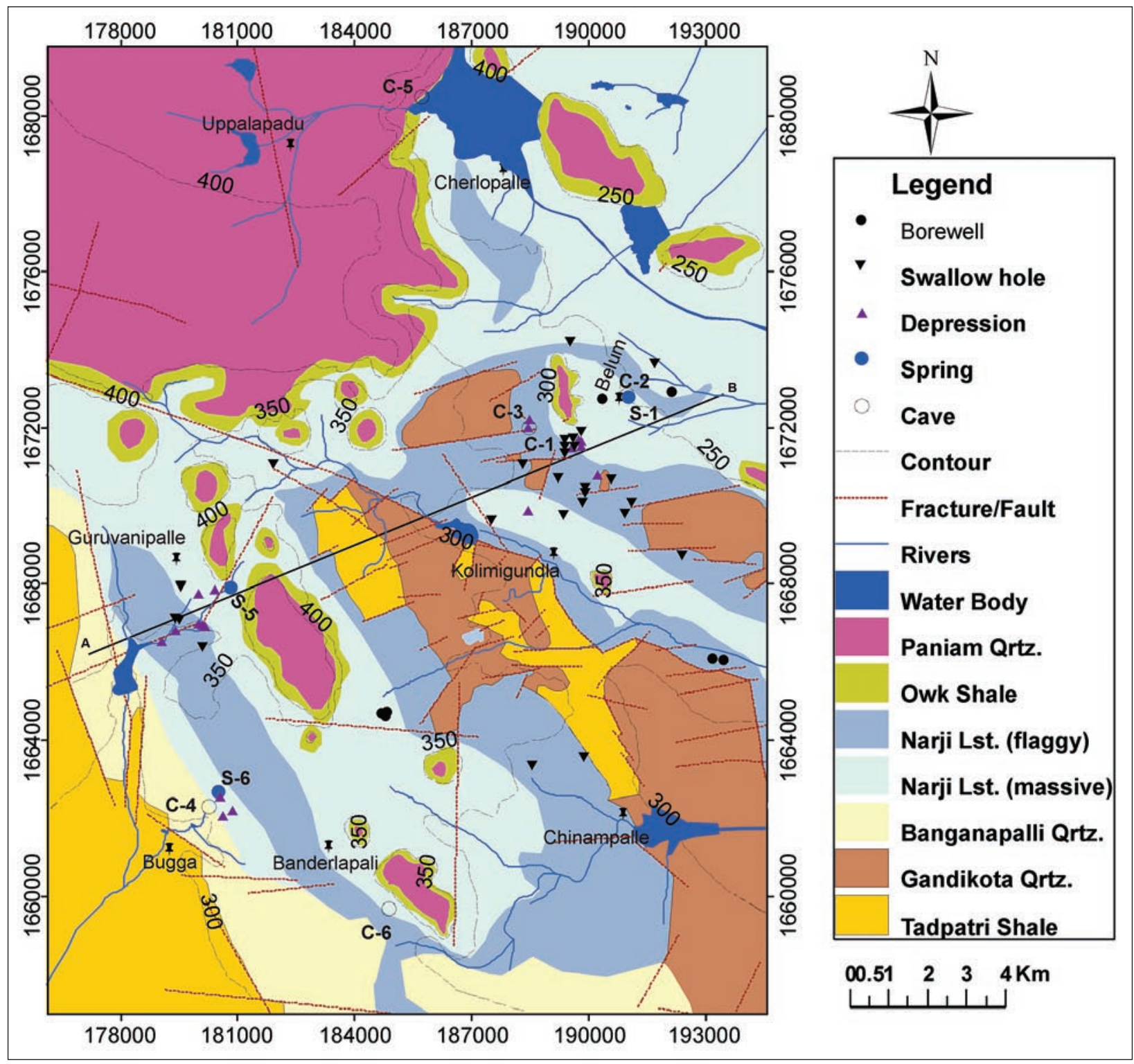

Fig. 6: Geological and geomorphological map of the Narji limestone plateau in Belum area with localization of observed karst features.

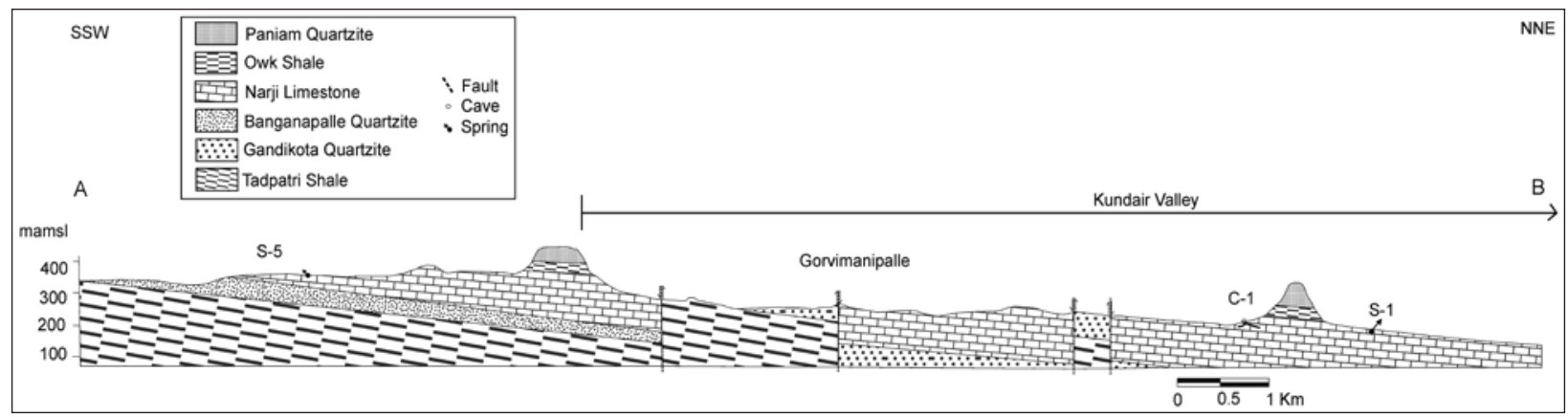

Fig. 7: Geological cross-section across the Narji limestone plateau, Belum area (the trace of the cross-section is indicated in Fig. 6).

rapid recession, typical of karst aquifers with high transmissivity in conduits (Fig. 9). Some depressions may store temporary water bodies that are used by livestock. It is also observed that point recharge occurs within the 


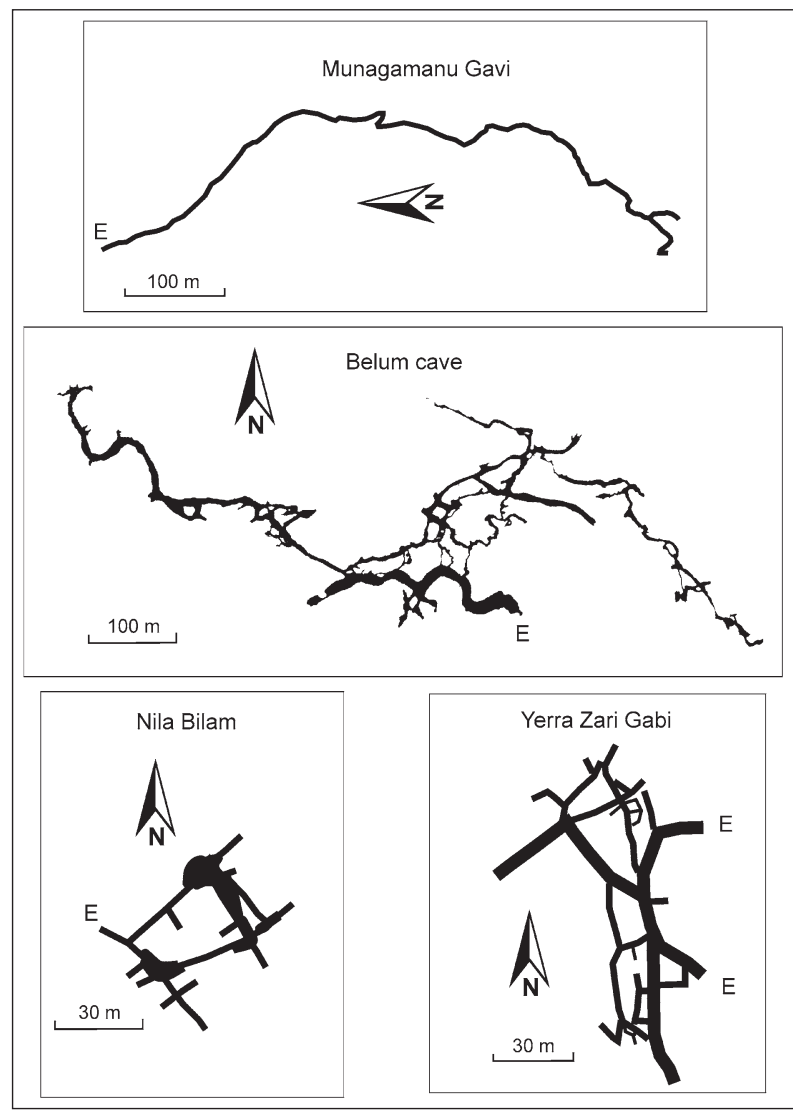

Fig. 8: Representative cave patterns that have developed in the Narji limestone.

limestone away from quartzite hills (e.g. the entrance of Belum cave acts as sinking points after heavy rainfall); it means that runoff is generated within the limestone plateau itself.

Seasonal streams have been observed in several caves: in Munugamanu cave (Figs. 5 \& 8: C7), the stream can be followed over several hundreds of meters in a canyon-type vadose gallery; peak discharge should be several $1 / s$ and flow is maintained $>0.11 /$ s several weeks after the end of the monsoon. In Bandarlapalle Guha (Fig. 6: C6), the stream can be followed in a phreatic conduit over $100 \mathrm{~m}$ between two sumps and has a discharge of several 1/s during the monsoon season. Finally, in Belum cave (Figs. 6, $7 \& 8: \mathrm{C} 1$ ) at the end of the touristic part, the temporary stream can be followed in phreatic conduits over several hundred meters. It flows after each recharge event (several 1/s) but dries up quite rapidly after.

Diffuse recharge seems to be limited as indicated by the absence of active speleothems (one exception in Munagamanu cave) even after rainfall events and the rapid decrease in spring discharges. However, epikarstic features are clearly observed in the massive limestone (Fig. 10) and they may have developed under more humid climatic conditions. This hypothesis can be supported by the relative abundance of inactive speleothems that are recorded in the Belum cave. These observations indicate that the limestone aquifer is mostly recharged by concentrated flow through swallow-holes and limited diffuse flow through the epikarst.

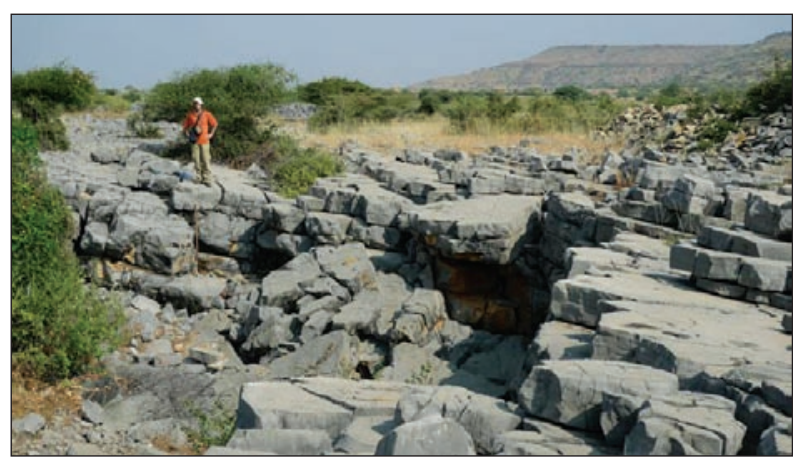

Fig. 10: Picture showing epikarst development in the Narji limestone: karrenfields in the massive unit.

Discharge of the aquifer occurs through seasonal and perennial karst springs (Tab. 2) and it is possible that significant flow feeds the confined limestone aquifer that develops to the East. Most springs (temporary as well as permanent) are observed on the western side of the Narji limestone plateau at or near the contact with the Tadipatri shale (free draining springs, Ford \& Williams 2007) (Fig. 6); on the eastern side, the Narji

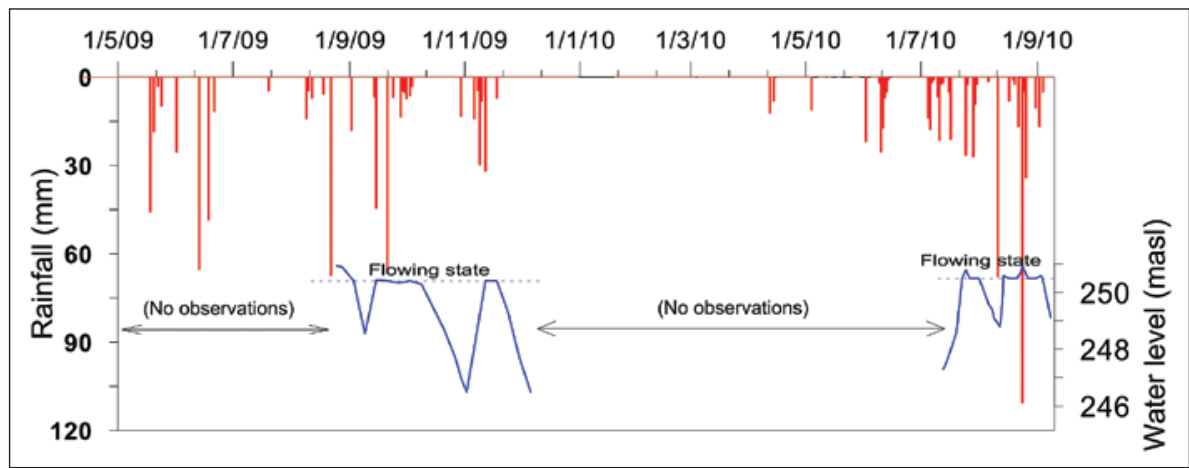

Fig. 9: Belum seasonal spring hydrograph (S2) showing a sharp response to the rainfall events typical of a karst aquifer. In general "no observations" correspond to periods when the spring was either dry or no data was collected. For location, refer to Fig. 1 \& 6. 
Tab. 2: Surveyed karst springs in the study area. Minimum and maximum discharges along with average electrical conductivity (at $25^{\circ} \mathrm{C}$ ) are indicated. The springs are located either on Fig. 1 or Fig. 6.

\begin{tabular}{|c|c|c|c|c|c|c|c|c|c|}
\hline \multirow{2}{*}{ ID } & \multirow{2}{*}{ Spring name } & \multirow{2}{*}{ Longitude } & \multirow{2}{*}{ Latitude } & \multirow{2}{*}{ Geology } & \multicolumn{2}{|c|}{ Discharge [I/s] } & \multirow{2}{*}{$\begin{array}{l}\text { Average EC } \\
{[\mathrm{uS} / \mathrm{cm}]}\end{array}$} & \multirow{2}{*}{$\begin{array}{l}\text { Specific } \\
\text { Discharge } \\
{\left[\mathrm{l} / \mathrm{s} / \mathrm{km}^{2}\right]} \\
\end{array}$} & \multirow{2}{*}{ Reference } \\
\hline & & & & & Min. & Max. & & & \\
\hline S1 & Belum Spring & $78^{\circ} 07^{\prime} 30.0^{\prime \prime}$ & $15^{\circ} 06^{\prime} 47.2^{\prime \prime}$ & Narji lim. & - & 50 & 674.6 & - & Gebauer 1983 \\
\hline S2 & Kona Spring-K1 & 77º54'24.54" & $15^{\circ} 08^{\prime} 56.5^{\prime \prime}$ & Narji lim. & 1.15 & 6.3 & 576.2 & 0.74 & Gebauer 1985 \\
\hline $\mathrm{S3}$ & Kona Spring-K2 & 7754'49.09" & $15^{\circ} 08^{\prime} 40.4^{\prime \prime}$ & Narji lim. & 0.31 & 0.83 & 628.4 & - & \\
\hline S4 & Kona Spring-K3 & 7754'26.89" & $15^{\circ} 09^{\prime} 33.47^{\prime \prime}$ & Narji lim. & 0 & $5^{*}$ & $708^{*}$ & - & \\
\hline S5 & Rati Spring & 7801'44.06" & $15^{\circ} 03^{\prime} 50.35^{\prime \prime}$ & Narji lim. & 0 & 15 & 594 & - & \\
\hline S6 & Bugga Spring & 7801'37.61" & $15^{\circ} 01^{\prime} 05.66^{\prime \prime}$ & Narji lim. & 0 & 13.8 & 1105 & - & \\
\hline S7 & Yaganti Spring & $78^{\circ} 08^{\prime} 23.27^{\prime \prime}$ & $15^{\circ} 21^{\prime} 03.07^{\prime \prime}$ & Narji lim. & 4.2 & 8.72 & 789.2 & - & \\
\hline S8 & $\begin{array}{l}\text { Chintalayapalli } \\
\text { Spring }\end{array}$ & 7756'39.29" & $15^{\circ} 05^{\prime} 43.14^{\prime \prime}$ & $\begin{array}{l}\text { Banganapalle } \\
\text { qrtz./Narji lim. }\end{array}$ & $?$ & $5.5^{*}$ & $485^{*}$ & - & \\
\hline S9 & $\begin{array}{l}\text { Kundanakota } \\
\text { Spring }\end{array}$ & $77^{\circ} 57^{\prime} 03.21^{\prime \prime}$ & $15^{\circ} 05^{\prime} 45.05^{\prime \prime}$ & $\begin{array}{l}\text { Banganapalle } \\
\text { qrtz./Narji lim. }\end{array}$ & $?$ & $11.5^{*}$ & $431^{*}$ & - & \\
\hline S10 & $\begin{array}{l}\text { Masanupalli } \\
\text { Spring }\end{array}$ & $77^{\circ} 58^{\prime} 10.01^{\prime \prime}$ & $15^{\circ} 05^{\prime} 38.11^{\prime \prime}$ & $\begin{array}{l}\text { Banganapalle } \\
\text { qrtz./Narji lim. }\end{array}$ & $?$ & $9.4^{*}$ & $545^{*}$ & - & \\
\hline
\end{tabular}

*data based on single value.

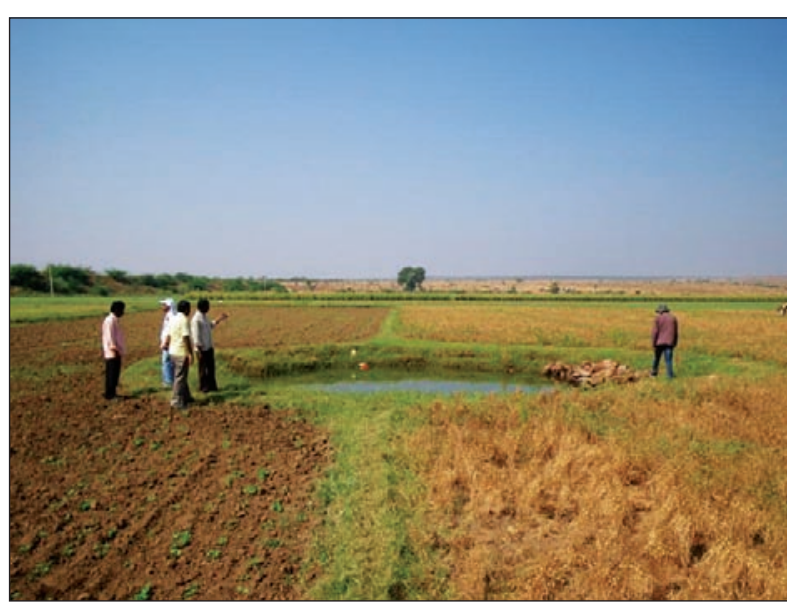

Fig. 11: Sinkhole in the Narji limestone that has opened in 2003 probably as a consequence of increased aquifer pumping, Nossam area.

limestone is progressively buried under younger formations and this setting favors confining flow conditions: only the seasonal spring of Belum (Tab. 2: S1) is known. It is observed that groundwater flow occurs

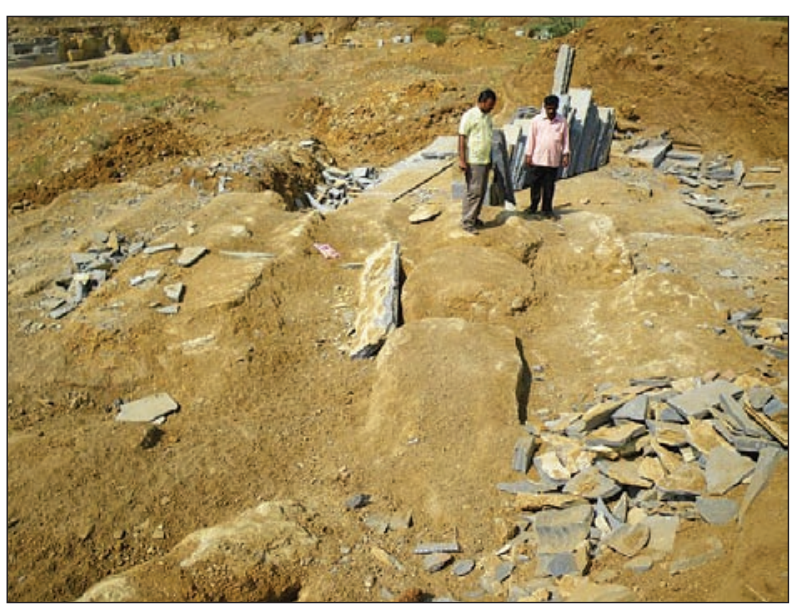

Fig. 13: Karrenfield developed below the soil zone in the Koilkuntla limestone as an indicator of epikarst development.

within the Narji limestone and the underlying Banganapalle quartzite at the base of which permanent and temporary springs are located (Tab. 2: S2, S8, S9 \& S10). Springs within the limestone flow seasonally as a

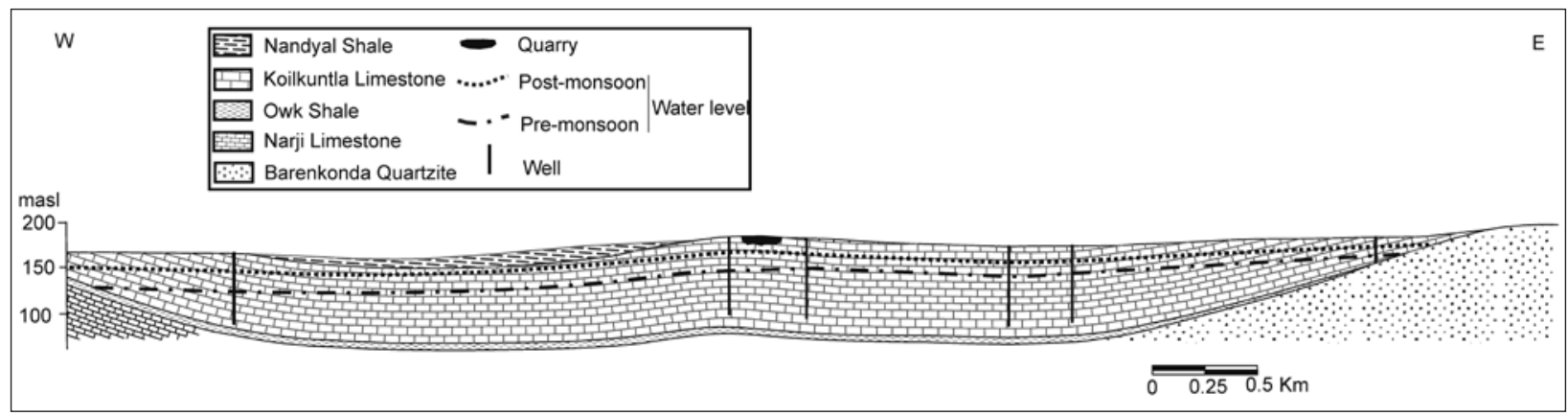

Fig. 12: Cross-section across the Koilkuntla limestone formation (the indicated quarry is also the location of Fig. 13). 
Tab. 3: Statistics of 1-year bimonthly data (abstraction rates (Q), static water levels (SWL), pumped water levels) from 84 irrigation wells drilled in the Koilkuntla limestone.

\begin{tabular}{|c|c|c|c|c|c|}
\hline & & Average & \begin{tabular}{|l|} 
Stand. \\
Deviation
\end{tabular} & \begin{tabular}{|l|} 
Coeff. \\
Variation
\end{tabular} & $N$ \\
\hline & Qmean $[\mathrm{l} / \mathrm{s}]$ & 9.4 & 2.6 & 0.27 & 84 \\
\hline & Qmin $[l / s]$ & 7.8 & 2.1 & 0.27 & 84 \\
\hline & Qmax [l/s] & 11.7 & 3.9 & 0.33 & 84 \\
\hline \multirow{3}{*}{ 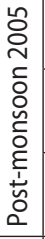 } & SWL [m b.g.l] & 12.8 & 8.0 & 0.63 & 79 \\
\hline & Drawdown [m] & 7.7 & 5.6 & 0.72 & 79 \\
\hline & Sp. Capacity [l/s/m] & 2.8 & 3.2 & 1.15 & 79 \\
\hline \multirow{3}{*}{ 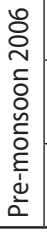 } & SWL [m b.g.l] & 26.5 & 11.7 & 0.44 & 79 \\
\hline & Drawdown [m] & 8.4 & 6.1 & 0.73 & 79 \\
\hline & Sp. Capacity [l/s/m] & 1.7 & 1.6 & 0.98 & 79 \\
\hline
\end{tabular}

result of piezometric surface rise (i.e. overflow) (Tab. 2: S5 \& S6). The spring S4 is located at higher level in the unsaturated zone of the Narji limestone at the floor of a surface drainage channel; in this case it may possibly drain the epikarst instead of being directly connected to the saturated zone. The aquifer is also tapped as wells for domestic use and irrigation. In Nossam area, a few sinkholes have developed since 2003-2004 with diameter between 2-5 $\mathrm{m}$ and depth 2-3 m, partly filled with water after monsoon (Fig. 11); some show an increase in diameter and depth with time.

\section{KARST FEATURES IN THE KOILKUNTLA LIMESTONE}

The Koilkuntla limestone has an average thickness of $90 \mathrm{~m}$ and bedding is nearly horizontal; it is underlain by Paniam quartzite and overlain by Nandyal shale (Fig. 12). The unit is well karstified as observed in quarries and an epikarst has developed (Fig. 13). However no caves are known possibly because of the absence of hilly terrains and the location of the water table close to the surface. The soil cover thickness varies from 0.5 to $>2 \mathrm{~m}$ and contains abundant pisoliths.

The aquifer is intensively exploited for irrigation as well as domestic use (Fig. 12). A database of 84 irrigation wells located in the limestone show high average discharge of $\sim 9 \mathrm{l} / \mathrm{s}$, (Tab. 3) and a very significant water table fluctuation between post-monsoon (average water table $12.8 \mathrm{~m}$ b.g.s.) and pre-monsoon (average water table $26.5 \mathrm{~m}$ b.g.s.). In addition to the drop in water table, the average specific capacity of the wells decreases significantly. This decrease may be partly due to larger head differentials which reduces pump discharge and also partly due to the desaturation of the upper part of the limestone aquifer. For instance, out of all the dataset, 14 wells have a specific capacity (i.e. the discharge divided by the drawdown) higher than $5 \mathrm{l} / \mathrm{s} / \mathrm{m}$. For 13 of these wells, the static water level (SWL) is $<20 \mathrm{~m} \mathrm{b.g.s.,} \mathrm{for} 8$ of them the SWL is $<11 \mathrm{~m}$. These data suggest a quite high permeability in the top $10 \mathrm{~m}$ of the limestone, possibly corresponding to the epikarst layer.

\section{DISCUSSION}

Field observations of caves, karst springs, swallow-holes, and karrenfields clearly indicate that the three carbonate formations of the Cuddapah sedimentary basin are karstified.

A specific question to be answered in semi-arid environments is to know whether observed karst has developed under present conditions or is inherited from past humid periods (Jennings 1983). The observed cave systems, being mostly inactive or only seasonally active, have developed during the Quaternary and possibly even earlier and it has been established that more humid conditions have prevailed during part of this period (Durand et al. 2007); these conditions have probably enhanced karstification processes. However, present hydrological observations in the Narji limestone indicate active flow in conduits feeding permanent and seasonal springs. This strongly suggests ongoing karst development and dissolution processes. It is not possible to be as assertive for the two other carbonate units because of lack of field evidence, however it is likely that dissolution processes are equally active since these carbonate aquifers are located in very similar contexts than the Narji limestone aquifer.

Combining geological, geomorphological, and cave patterns information, it is possible to propose a tentative history of karstification for the Narji limestone (Fig. 14) which is the unit having the largest accessible cave system. In the earlier stage, it is inferred that network maze caves have developed in a confined limestone aquifer setting where diffuse infiltration took place across 


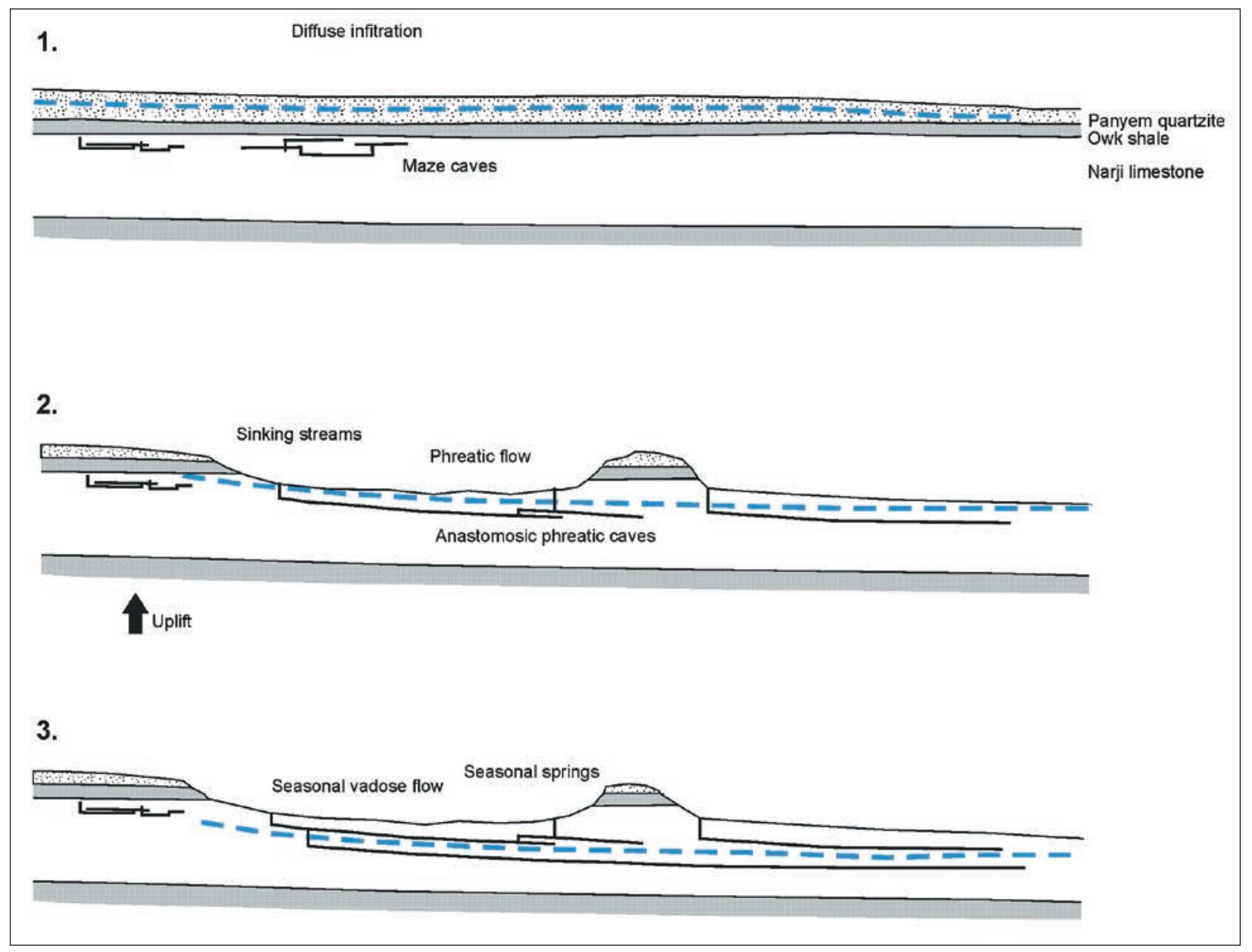

Fig. 14: A karstification conceptual model of the Narji limestone: 1) initial phase with development of maze cave system in a confined setting; 2) following tectonic uplift, the limestone is progressively exposed to the surface and anastomosic phreatic cave systems develop; 3) the water table gets progressively lower inducing a lower level of karstification (present state).

quartzite and shale layers similarly to the conceptual model of Palmer $(1991,2007)$. This event is believed to be Pre-Pliocene during more humid conditions prior to the onset of monsoonal conditions and Western Ghats uplifting at $\sim 8 \mathrm{Ma}$. During this period, the sea level was more than $\sim 100 \mathrm{~m}$ higher than the present level (Haq et al. 1987).

The fact that these relict maze caves (Nila Bilam, Yerra Zari Gabi, Fig. 8) are located near the top of the limestone series seems to corroborate this type of development. This model requires a significant permeability of the quartzite and shale, possibly initiated by the preuplifting compressional forces, so as diffuse infiltration can take place. After Early-Pliocene, a eustatic fall in sea-level along with the Western Ghats denudational rebound (uplift and tilting of relief to the east (Radhakrishna 1952; Vaidyanadhan 1964) occurred. This event is believed to cause structural compartmentalization and fragmentation that enhanced denudation rates along the Eastern Ghats margin controlled by the structural pattern of the resistant rock outcrops viz, Charnokites, Cuddapah sandstones and quartzites (Gunnell 1998a). The entire instability event caused a $\sim 300 \mathrm{~m}$ surface uplift in the Western Ghats (Gunnell \& Fleitout 1998), with the harder rocks being comparatively more uplifted (Gunnell \& Louchet 1998) than their softer counterparts.

Following tectonic uplifting, a positive relief favored surface runoff and progressive erosion of the quartzite and shale which resulted in the exposure of Narji limestone at the earth surface. The uplifting of Western Ghats and the onset of monsoon ( $~ 8 \mathrm{Ma})$, caused more humidity on the west coast of India, while the entire southern India was subjected to a long lasting aridification and developed characteristics of semi-arid landscapes (Gunnell 1998b).

Thus, piezometric surfaces readjusted to lower base levels, maze cave systems became inactive (relict caves), and the limestone aquifer became unconfined. This set- 
ting supported the development of phreatic conduits (e.g. Belum cave) fed by sinking streams issued from quartzite hills and diffuse infiltration through the limestone plateau. However, the aridification was itself responsible for the initiation of seasonal contrasts and more intense precipitation regimes (Gunnell 1998a). During rapid and frequent sea level fluctuating Quaternary, more humid conditions (e.g. Durand et al. 2007) may have promoted the incision of deeper cave systems and the development of the existing ones. Further erosion of the land surface resulted in additional lowering of piezometric surfaces and the readjustment of the conduit systems (vadose conditions in the upper part of the limestone with associated development of canyon type conduits, progressive dissolution of a deeper level of phreatic conduits). This stage is still ongoing nowadays with an active inaccessible conduit network at greater depth and a seasonally active vadose flow in the explored caves.

Ford \& Williams (2007) propose a linear relationship between electrical conductivity (EC) and total hardness $(\mathrm{TH})$. Using this relationship and the average EC measured at Kona springs (Tab. 2: S2 \& S3), average TH is $296 \mathrm{mg} / \mathrm{l}$ as $\mathrm{CaCO}_{3}$. For the same spring, the specific discharge is estimated to be $0.98 \mathrm{l} / \mathrm{s} / \mathrm{km}^{2}$ (or $23.3 \mathrm{~mm} / \mathrm{a}$ ). Using Corbel formula (e.g. Ford \& Williams 2007), the denudation rate is therefore $3.7 \mathrm{~mm} / \mathrm{ka}$. Even if this data should be taken as a crude estimate, it is in the same range as denudation rates estimated in arid climatic conditions in Australia (e.g. Stone et al. 1994).

It is proposed to consider these three carbonate formations as karstified and undergoing active karstification processes. This has an important bearing on the hydrological functioning of these aquifers which need to be discussed in more detail. Recharge of the limestone aquifers occur during the monsoon months (June to November) only after significant rainfall (average 5-7 recharge events per year): runoff on non-carbonated hilly terrains (mostly quartzite) is the main source of point recharge through swallow-holes located in the limestone plateau near the foothills. Significant runoff is also generated within the limestone areas and may recharge the aquifer through swallow-holes (as seen near the entrance of Belum cave) but also contribute to surface flow (a well developed drainage pattern can be observed on the limestone/dolomite areas indicating significant surface runoff). Finally some recharge may occur as diffuse infiltration through the soil zone and epikarst; this type of recharge seem to be quite limited as very few drip flow is observed in cave systems even after significant rain events.

In the Narji limestone, a large part of the aquifer transmissivity occurs as conduit flow feeding karstic springs. In the massive part of the limestone, it seems that conduits provide the predominant permeability as indicated by several dry wells drilled by farmers and during the touristic development of Belum cave; in the flaggy part of the Narji limestone and in more fractured zones (e.g. near the contact with quartzite), additional permeability by bedding planes and joints is likely since irrigation wells with good sustained flow (average discharge $7-81 / s$ ) have been implemented.

The permanent springs (Fig. 1: S2, S3, S8, S9 \& S10) are situated only at the western foothills of the limestone plateau, with no such permanent spring existing in the nearby eastern foothills where the human activities have significantly modified the natural landscape: a high density of paddy fields irrigated by canal water issued from a river/reservoir. Either pre-existing springs are presently concealed by theses modifications or a regional flow system has developed (i.e. deeper circulation in the Narji Limestone to the east) with no local discharge.

In the Koilkuntla limestone, it seems clear that the fracture system provide significant permeability because of the large number of irrigation wells with moderate yields that are observed; the role of conduit flow is unclear but probably contributes to the larger yields observed on some wells. Data show that a significant part of well discharge is provided by the upper part of the limestone aquifer, which is indicative of a higher permeability. This may be partly attributed to the existence of a well-developed epikarst layer as suggested by Fig. 13.

The studied karst region presents several characteristics of karst in arid and semi-arid regions as described by Ford \& Williams 2007. The karstic landscape is less developed than in more humid setting with a limited number of dolines, preponderance of runoff and evaporation over infiltration, which results in modest spring flow and even of a majority of springs being seasonal (Tab. 2), predominance of point recharge over diffuse infiltration, and a lower density of caves. The specific geological setting of the studied area with widespread distribution of quartzite hillocks creates favourable conditions for karstification: significant runoff generated on the hillocks provides aggressive water (i.e. dilute runoff water with low $\mathrm{pH}$ ) which will infiltrate the karst through swallow-holes and have a good potential for active limestone dissolution. Diffuse infiltration taking place across the $\mathrm{CO}_{2}$-rich soil zone will also contribute to limestone dissolution within the underlying epikarst layer. However, due to the present climatic conditions combining low rainfall with high evaporation rates, diffuse infiltration and dissolution fluxes are believed to be quite limited.

Because of the flashy nature of rainfall events (high rainfall intensity), a significant part of the generated runoff will also remain as surface flow as indicated by the surface drainage pattern observed on the limestone 
plateau. As a result, the general morphology has a strong fluvial component and the karst morphology is limited to specific areas.

Field data suggest the presence of a well-developed epikarst in the Narji and Koilkuntla limestone. However, its role on the hydrological functioning of the aquifer is not clear and it may well not control significantly present recharge conditions.

\section{CONCLUSIONS}

Field observations indicate the extensive karstification of the three carbonate formations present within the Cuddapah sedimentary basin, namely the Vempalle dolomite, the Narji and Koilkuntla limestone, which together cover about $17 \%$ of this basin. The karstic nature of these formations need to be acknowledged and considered in future development/management activities such as civil engineering work, water management, land management, etc.

A widespread concern in semi-arid regions is the scarcity of water resources and the need to have adequate water resource management tools. Due to intensive irrigated agriculture, parts of the limestone aquifers of the Cuddapah sedimentary basin are overexploited (e.g. Rao et al. 2001). The management tools needed to reverse these observed water table declining trends have to be based on an adequate understanding of the aquifer hydrogeological characteristics (recharge, permeability, storage).

Another striking feature of the region is the abundance of quarries either for extraction of construction slabs (in Belum area their extent increased from $9.7 \mathrm{~km}^{2}$ in 1983 to $25.6 \mathrm{~km}^{2}$ in 2010) or for cement factories. Their impact on groundwater recharge and balance is being assessed in an ongoing project but additional impacts on land surface temperature (Xiao \& Weng 2007), landscape and water quality (Gunn et al. 1993) are expected to occur.

There is a need for more detailed studies on karstification and the structure and functioning of these karst aquifers. A better understanding of these aquifers is essential for the adequate estimation of groundwater reserve, their sustainable exploitation, and also for the implementation of management policies aiming at protecting the quantity and quality of the resource. These karst water resources are essential to the local communities for domestic use and agricultural production.

Dams for irrigation are being built in the region to capture runoff from quartzite hills and the impoundments are at least partly in contact with karstified rocks; in this case, important and unexpected leakage may occur due to karst permeability.

\section{ACKNOWLEDGMENTS}

The first author is thankful to the Director, NGRI (CSIR) Hyderabad for permitting to publish this work. Farooq Ahmad Dar is grateful to UGC and French embassy for fellowship. Authors thank Dr. Krishniah, Mr. Nagmuniah, Mr. Babu (Belum cave employees) and Mr. Wajidud-Din for their continued support in the field work ac- tivities. The NGO BIRDS agreed to share data from their APFAMGS project.

The authors also thank Dr. Paul Williams and an anonymous reviewer for their helpful and constructive comments in reviewing the paper. 


\section{REFERENCES}

Anand, M., Gibson, S.A., Subbarao, K.V., Kelley S.P. \& A.P. Dickin, 2003: Early Proterozoic Melt Generation Processes beneath the Intra-cratonic Cuddapah Basin, Southern India.- Journal of Petrology, 44, 12, 2139-2171.

Balakrishna, S. \& B.E. Vijayam, 1968: Sedimentation of non-clastics in the western part of the Cuddapah basin.- Bull. Nat. Geophys. Res. Inst., 6, 2, 51-67.

Chandra, P.C., Satyanarayana T. \& K.C.B. Raju, 1987: Geoelectrical response of cavities in limestones: An experimental field study from Kurnool District, Andhra Pradesh, India.- Geoexploration, 24, 6, 483-502.

Coward, J.M.H., Waltham, A.C. \& R.J. Bowser, 1972: Karst springs in the Vale of Kashmir.- Journal of Hydrology, 16, 213-233.

Crawford, A.R., \& W. Compston, 1973: The Age of the Cuddapah and Kurnool Systems, Southern India.Journal of the Geological Society of Australia, 19, $4,453-464$.

Dubey, D.P., Tiwari, R.N. \& U. Dwivedi, 2006: Evaluation of Pollution Susceptibility of Karst Aquifers of Rewa Town (Madhya Pradesh) Using "DRASTIC" Approach.- Journal of Environ. Science \& Engg. 48, 2, 113-118.

Durand, N., Gunnell, Y., Curmi, P. \& S.M. Ahmad, 2007: Pedogenic carbonates on Precambrian silicate rocks in South India: Origin and palaeoclimate significance.- Quaternary International, 162-163, 35-49.

Dutt, N.V.B.S., 1962: Geology of Kurnool System of rocks in Cuddapah and the Southern part of Kurnool District.- Rec. Geol. Surv. India, 87, 549-694.

Dutt, N.V.B.S., 1975: Geology and mineral resources of Andhra Pradesh.- Ramesh Publ., pp. 205, Hyderabad.

Ford, D.C. \& P. Williams, 2007: Karst Hydrogeology and Geomorphology.- John Wiley \& Sons, Ltd, pp. 562, Chichester.

Gebauer, H.D. \& A. Abele, 1983: Caves of India and Nepal / Höhlen von India und Nepal.- Schwäbisch Gmünd \& Ölmühle: Gebauer, pp. 166.

Gebauer, H.D., 1985: Kurnool 1984: Report of the speleological expedition to the district of Kurnool, Andhra Pradesh, India.- Abhandlungen zur Karst und Höhlenkunde, 21, pp. 77.

Gebauer, H.D., 1997: Indien 1996/97: Kurnool, JaypurJagdulpur und Meghalaya.- Mitt. Verb. dt. Höhlenu. Karstforsch, 43, 4, 104-111.

Geological Survey of India, 1997: Cuddapah geological quadrangle map series, 1:250,000.- Kolkata.
Gunn, J. \& D. Bailey, 1993: Limestone quarrying and quarry reclamation in Britain.- Environmental Geology, 21, 3, 167-72.

Gunnell, Y., 1998a: The interaction between geological structure and global tectonics in multistoried landscape development: a denudation chronology of the South Indian shield.- Basin Research, 10, 281-310.

Gunnell, Y., 1998b: Passive margin uplifts and their influence on climatic change and weathering patterns of tropical shield regions.- Glob. Planet. Change, $18,47-57$.

Gunnell, Y. \& A. Louchet, 1998: The influence of rock hardness and divergent weathering on the interpretation of apatite fission track denudation rates: evidence from charnockites in South India and Sri Lanka.- Zeitschrift für. Geomorphologie, 44, 4, 481-504.

Gunnell, Y. \& L. Fleitout, 1998: Morphotectonic evolution of the Western Ghats, India.- In: Summerfield, M.A. (ed.) Geomorphology and Global Tectonics.John Wiley \& Sons, pp. 368, Chichester.

Haq, B.H., Hardenbol, J. \& P.R. Vail, 1987: The chronology of fluctuating sea level since the Triassic.- Science, 235, 1156-1167.

Jeelani, G., 2008: Aquifer response to regional climate variability in part of Kashmir Himalaya in India.Hydrogeology Journal, 16, 1625-1633.

Jennings, J.N., 1983: The disregarded karst of the arid and semiarid domain.- Karstologia, 1, 61-73.

Jhanwar, M.L., Rajurkar, S.T. \& P.N. Phadtere, 1964: Stratigraphy of the Vempalle formation of Cuddapah basin.- J. Indian Geosc. Ass., 4, 43-62.

Kaila, K.L., Roy Chowdhury, K., Reddy, P.R., Krishna, V.G., Narain, H., Sabbotin, S.I., Sollogub, V.B., Chekunov, A.V., Kharetchko, G.E., Lazarenko, M.A. \& T.N. Ilchenko, 1979: Crustal structure along Kavali--Udipi profile in the Indian Peninsular shield from Deep Seismic Sounding.- J. Geol. Soc. India, 20, 307-333.

Kaila, K.L. \& H.C. Tewari, 1985: Structural trends in the Cuddapah basin from deep seismic soundings (DSS) and their tectonic implications.- Tectonophysics, 115, 69-86.

Kailasam, L.N., 1976: Geophysical studies of the major sedimentary basins of the Indian craton, their deep structural features and evolution.- Tectonophysics, $36,1-3,225-245$.

Kale, V., 1991: Constraints on the evolution of the Purana basins of peninsular India.- J. Geol. Soci. India, $38,231-252$. 
Kamal, M.Y., 1974: Sedimentology and Sedimentary tectonics of the Kurnool system, near Kurnool.- Unpublished PhD thesis, Osmania University, Hyderabad.

Kamal, M.Y. \& B.E. Vijayam, 1981: Sedimentary tectonics of the Kurnool Cuddapah basin.- In: Fourth workshop on status, problems and programmes in Cuddapah basin. Indian Inst. Peninsular Geol., pp. 75-85, Hyderabad.

Kasipathi, C., Arjunudu, K., Rao, K.S. \& M.S. Rao, 2008: Cuddapah Formations of Andhra Pradesh, India. A New Report of Prospects for Rich Banded Iron Ore Formation.- Canadian Journal of Pure and Applied Sciences, 2, 1, 227-233.

King, W., 1872: Kadapah and Kurnool formations in the Madras presidency.- Geol. Surv. Ind. Mem., 8.

Kumar, J.V., 1983: Geological and hydrogeological studies of part of Cuddapah basin.- $\mathrm{PhD}$ thesis. Osmania University, Hyderabad.

Meijerink, A.M.J., Rao, D.P. \& J. Rupke, 1984: Stratigraphic and structural development of the Precambrian Cuddapah Basin, SE India.- Precambrian Research, 26, 57-104.

Murty, K.S., 1988: Karst Hydrogeology: India.- In: Karst Hydrogeology and Karst Environment Protection. IAH, $21^{\text {st }}$ Congress, 10-15 October 1988, 446-450, Guilin, China.

Murthy, Y.G.K., Setti, T.L.N., Rajurkar, S.T., Meoloi, S.H., Nagaraja Rao, B.K., Ramaligaswami, G., Madan Mohan, B. \& R. Ravindra Babu, 1979: Salient features of the revised geological map of the Cuddapah basin.- In: Third workshop on status and problems in Indian Peninsular shield, Inst. Of Indian Peninsular Geology, Hyderabad.

Murthy, Y.G.K., 1981: The Cuddapah Basin- A Review of Basin Development and Basement Framework Relations.- In: Fourth workshop on status, problems and programs in Cuddapah Basin, Inst. Of Indian Peninsular Geology, 51-73, Hyderabad.

Nagaraja Rao, B.K., Rajaurkar, S.T. \& G. Ramalingaswamy, 1987: Stratigraphy, Structure and Evolution of the Cuddapah Basin.- Mem. Geol. Soc. India, 6, 33-86.

Narayanaswami, S., 1966: Tectonics of Cuddapah Basin.J. Geol. Soc. Ind., 7, 33-50.

Palmer, A.N., 1991: Origin and morphology of limestone caves.- Geol. Soc. Am. Bull., 103, 1-21.

Palmer, A.N., 2007: Cave Geology.- Cave Books, pp. 454, Dayton, Ohio.

Pascoe, E.H., 1950: A Manual of the Geology of India and Burma.- Delhi, Govt., $1-3^{\text {rd }}$ ed.
Qureshi, M.N., Krishna-Brahman, N., Aravamadhu, P.S. \& S.M. Naqvi, 1968: Role of granitic intrusions in reducing the density of the crust and other related problems as illustrated from a gravity study of the Cuddapah Basin, India.- Proc. R. Soc., 304, 449464.

Radhakrishna, B.P., 1952: The Mysore Plateau, its structural and physiographic evolution.- Bull. Mysore Geologists Assoc, 3, 1-53.

Raju, R.D., 2009: Cuddapah Basin: India's Emerging Uranium-Hub.- Jour. Indian Association of Sedimentologists, 28, 2, 15-24.

Ramam, P.K. \& V.N. Murthy, 1997: Purana basins: Cuddapah, Pakhal, Bhima.- In: Geology of Andhra Pradesh, Geological Society of India, 119-136, Bangalore.

Rao, P.B., Subrahmanyam, K. \& R.L. Dhar, 2001: Geoenvironmental effects of groundwater regime in Andhra Pradesh, India.- Environmental Geology, 40, 4-5, 632-642.

Riding, R. \& M. Sharma, 1998: Late Palaeoproterozoic ( 1800-1600 Ma) stromatolites, Cuddapah Basin, southern India: cyanobacterial or other bacterial microfabrics?- Precambrian Research, 92, 21-35.

Roy, A.K., 1947: Geology of the Dhone taluk and neighbouring parts, Kurnool districts.- Unpublished Geological Survey of India Progress Report (19451946)

Sen, S.N. \& R. Narsimha, 1968: Igneous activity in Cuddapah Basin and adjacent areas and suggestions on the palaeogeography of the Basin. In: Proc. Symp. Upper Mantle Project, January 1967, Hyderabad (India), Session V, 261-285.

Shibasaki, T., Balakrishna, S., Yoshimura, T., Venkatanarayana, B., Furukama, H., Venkateswara, R.T., Chuman, N., Ramanohan, R.Y. \& K. Venkateswaralu, 1985: Karstification process of carbonate rocks in the Cuddapah sedimentary Basin, Indian Peninsular Shield.- J. Fac. Mar. Sci. Technol., Tokai Univ., 21, 31-45.

Singh, Y. \& D.P. Dubey, 2001: Quality of groundwater in shallow and deep karst and other associated aquifer zones of central India.- In: $8 t^{h}$ Multidisciplinary Conference on Sinkholes and the Engineering and Environmental Impacts of Karst, April 2001, USA, AA Balkema publishers, 259-264.

Singh, A.P. \& D.C. Mishra, 2002: Tectonosedimentary evolution of Cuddapah basin and Eastern Ghats mobile belt (India) as Proterozoic collision: gravity, seismic and geodynamic constraints.- Journal of Geodynamics, 33, 249-267. 
Stone, J., Allan, G.L. \& L.K. Fifield, 1994: Limestone erosion measurements with cosmogenic chlorine-36 in calcite - preliminary results from Australia.- Nuclear Instruments and Methods in Physics Research, Series B, 92, 311-316.

UNEP, 1992: World Atlas of Desertification.- Edward Arnold, pp. 182, London.

Vaidyanathan, R., 1961: Stromatolites in lower Cuddapah limestones (Precambrian).- Current Science, 30, 221.

Vaidyanadhan R., 1964: Recognition and correlation of erosion surfaces in and around the southern part of the Cuddapah Basin.- J. Geol. Soc. Ind., 5.

Venkatanarayana, B. \& T.V. Rao, 1989: Geological and geophysical investigations for delineating karstic structures of the southwestern portion of Cuddapah basin, Andhra Pradesh, India.- In: Berry, B.F. (ed.) Proc. of $3^{\text {rd }}$ Multidisciplinary Conference on Sinkholes and the Engineering and Environmental Impacts of Karst, Oct. 1989, USA, AA Balkema publishers, 59-64.
Venkatanarayana, B., Ahmed, S. \& V. Agnihotri, 1999: The hydrogeology of the Kuteshwar limestone deposits, Madhya Pradesh, India.- Journal of Environmental Hydrology, 7, 5, 1-13.

Vijayam, B.E., 1968: Worm burrows in Narji Limestone near Govindine.- Current science, 37, 5, 142.

Vijayam, B.E., Kamal, M.Y. \& K. Veeriah, 1981: Sedimentation in the Kurnool group.- In: Fourth workshop on status, problems and programmes in Cuddapah basin, Indian Inst. Peninsular Geol., Hyderabad.

Vittal, K.P.R., Basu, M.S., Chary, G.R., Sankar, G.R.M., Srijaya, T., Ramakrishna, Y.S., Samra, J.S. \& G. Singh, 2004: District wise Promising Technologies for Rainfed Groundnut based Production System in India. In: All India Coordinated Research Project for Dryland Agriculture Central Research Institute for Dryland Agriculture Santoshnagar, Hyderabad.

Xiao, H. \& Q. Weng, 2007: The impact of land use and land cover changes on land surface temperature in a karst area of China.- Journal of Environmental Management, 85, 245-257. 